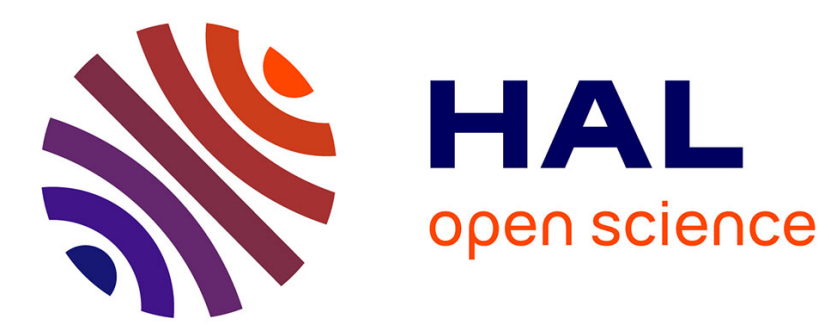

\title{
LPS structure influences protein secretion in
}

\author{
M. Crhanova, M. Malcova, M. Mazgajova, D. Karasova, A. Sebkova, A.
}

Fucikova, Z. Bortlicek, L. Pilousova, K. Kyrova, M. Dekanova, et al.

\section{To cite this version:}

M. Crhanova, M. Malcova, M. Mazgajova, D. Karasova, A. Sebkova, et al.. LPS structure influences protein secretion in. Veterinary Microbiology, 2011, 152 (1-2), pp.131. 10.1016/j.vetmic.2011.04.018 . hal-00719079

\section{HAL Id: hal-00719079 \\ https://hal.science/hal-00719079}

Submitted on 19 Jul 2012

HAL is a multi-disciplinary open access archive for the deposit and dissemination of scientific research documents, whether they are published or not. The documents may come from teaching and research institutions in France or abroad, or from public or private research centers.
L'archive ouverte pluridisciplinaire HAL, est destinée au dépôt et à la diffusion de documents scientifiques de niveau recherche, publiés ou non, émanant des établissements d'enseignement et de recherche français ou étrangers, des laboratoires publics ou privés. 


\section{Accepted Manuscript}

Title: LPS structure influences protein secretion in Salmonella enterica

Authors: M. Crhanova, M. Malcova, M. Mazgajova, D. Karasova, A. Sebkova, A. Fucikova, Z. Bortlicek, L. Pilousova, K. Kyrova, M. Dekanova, I. Rychlik

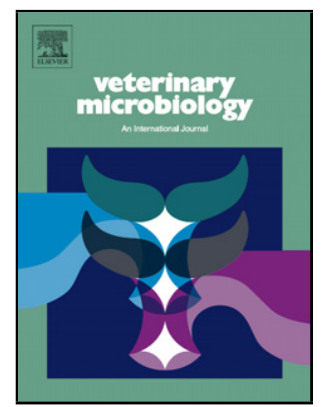

PII:

DOI:

Reference: S0378-1135(11)00232-X

To appear in: $\quad$ VETMIC

Received date: $\quad 3-12-2010$

Revised date: $\quad 9-4-2011$

Accepted date: $\quad$ 14-4-2011

Please cite this article as: Crhanova, M., Malcova, M., Mazgajova, M., Karasova, D., Sebkova, A., Fucikova, A., Bortlicek, Z., Pilousova, L., Kyrova, K., Dekanova, M., Rychlik, I., LPS structure influences protein secretion in Salmonella enterica, Veterinary Microbiology (2008), doi:10.1016/j.vetmic.2011.04.018

This is a PDF file of an unedited manuscript that has been accepted for publication. As a service to our customers we are providing this early version of the manuscript. The manuscript will undergo copyediting, typesetting, and review of the resulting proof before it is published in its final form. Please note that during the production process errors may be discovered which could affect the content, and all legal disclaimers that apply to the journal pertain. 
$1 \quad$ LPS structure influences protein secretion in Salmonella enterica

2

3 Running title: Salmonella LPS mutants and protein secretion

4

5 Crhanova M. ${ }^{1 \&}$, Malcova, M. ${ }^{1 \&}$, Mazgajova, M. ${ }^{1 \#}$, Karasova, D., Sebkova, A., Fucikova,

$6 \quad$ A. $^{2}$, Bortlicek, Z. ${ }^{3}$, Pilousova L. ${ }^{1}$, Kyrova K. ${ }^{1}$, Dekanova M. ${ }^{1}$, Rychlik, I. $^{{ }^{*}}$

7

$8 \quad{ }^{1}$ Veterinary Research Institute, Hudcova 70, 62100 Brno, Czech Republic

$9 \quad{ }^{2}$ Institute of Molecular Pathology, Faculty of Military Health Sciences, University of

10 Defense, Trebesska 1575, 50001 Hradec Kralove, Czech Republic

$11{ }^{3}$ Institute of Biostatistics and Analyses, Faculty of Medicine and Faculty of Science, Masaryk

12 University, Kamenice 126/3, 62500 Brno, Czech Republic

13

$14 *$ Corresponding author

15 Ivan Rychlik, Veterinary Research Institute, Hudcova 70, 62100 Brno, Czech Republic

16 phone +420 533331201, fax +420 541211229, E-mail: rychlik@ vri.cz

17

18 \# Present address: Institute of Molecular Pathology, Faculty of Military Health Sciences,

19 University of Defense, Trebesska 1575, 50001 Hradec Kralove, Czech Republic

$21 \&$ contributed equally to this work 


\section{3}

24

\section{Abstract}

In this study we have compared protein secretion in the wild type of $S$. Typhimurium and the $r f a C$ mutant. We found out that the $r f a C$ mutant was defective in protein secretion. In addition, the $r f a C$ mutant was defective in its invasion into an IPEC-J2 porcine epithelial cell line and also in motility in semisolid agar. Consistent with this, reduced flagella numbers were observed in the $r f a C$ mutant. In the $r f a C$ mutant, there were no defects in flagellin expression as detected by western blot and immune electron microscopy which demonstrated equal amounts of flagellin in the cytoplasm of both the $r f a C$ mutant and the wild-type $S$. Typhimurium. However, in the wild-type strain only, the flagellin was assembled to spatially restricted areas on the inner side of cytoplasmic membrane. The oligosaccharide core of LPS is therefore required for the assembly of flagella and T3SS secretion machinery followed by protein secretion.

\section{Keywords}

Salmonella; LPS; rfaC; protein secretion; motility; SPI-1 


\section{Introduction}

40 Salmonella enterica is a pathogen of many bird and mammalian species including humans. Its pathogenicity is dependent on type III secretion systems (T3SS) and nearly all the proteins found in nutrient rich media after $S$. enterica culture are those transported by T3SS (Komoriya et al., 1999). There are 3 different T3SS in S. enterica (Hautefort et al., 2008). The first one is used for the transport of flagellar proteins and the assembly of flagella on the surface of bacterial cells. The remaining two T3SS are tightly associated with $S$. enterica virulence. The T3SS encoded by Salmonella pathogenicity island 1 (SPI-1) is involved in $S$. enterica invasion into epithelial cells (Kaniga et al., 1995) and the last T3SS encoded by Salmonella pathogenicity island 2 (SPI-2) is involved in intracellular survival of S. enterica (Cirillo et al., 1998).

To protect humans or farm animals against Salmonella infections, different live or inactivated vaccines have been tested. Besides the vaccination against Salmonella infections, S. enterica is also frequently used as a vector for the expression and delivery of heterologous antigens (Panthel et al., 2005). However, while the attenuation and immunogenicity have been tested experimentally many times, the pattern of protein secretion has not been addressed thoroughly. It is known that mutants defective in the synthesis of full-sized LPS show impaired motility (Parker et al., 1992; Karasova et al., 2009) which may indicate a defect in the secretion of flagellar proteins. In this study we were therefore interested in the secretion of flagellar and SPI-1-encoded T3SS proteins by $r f a C$ mutant of Salmonella enterica serovar

60 Typhimurium ( $S$. Typhimurium). This mutation conveys defect in the synthesis of the oligosaccharide core of LPS and therefore produce an oligosaccharide core free LPS (Parker et al., 1992; Sirisena et al., 1992; Genevaux et al., 1999). We found out that secretion of flagellar and SPI-1-encoded proteins required the presence of an intact oligosaccharide core 
of LPS and that this defect is caused most likely by the inability to set up the T3SS

translocation machinery.

\section{Material and Methods}

\section{Bacterial strains and growth condition}

$S$. Typhimurium strain LT2, its $r f a C$ mutant and the $r f a C$ mutant complemented with a recombinant plasmid encoding $r f a C$ has been used in this study. The deletion of $r f a C$ in $S$. Typhimurium was constructed exactly as described previously for $S$. Enteritidis (Sebkova et al., 2008). For complementation, the $r f a C$ gene was amplified by PCR using forward (CTCGGCAAAAGACCATGAAG) and reverse (TCCACAATAGGTTTGGGATG) primers and the resulting PCR product was cloned into pCR2.1 using the TOPO cloning system according to the instructions of the manufacturer (pCR2.1 TOPO Cloning kit, Invitrogen). After selection by PCR using primers flanking the plasmid-insert junction, the pRfaC plasmid was electroporated into $S$. Typhimurium $r f a C$ mutant. All the strains were stored in LB broth with $10 \%$ glycerol at $-70{ }^{\circ} \mathrm{C}$ and when in use, the strains were grown in LB broth or LB agar at $37^{\circ} \mathrm{C}$ supplemented with antibiotics if appropriate. Motility was determined by inoculation of $1 \mu \mathrm{l}$ of 18 -hour-old culture into the centre of Petri plate with $0.3 \% \mathrm{LB}$ agar and by measuring the diameter of bacterial growth 8 hours later.

\section{SDS-PAGE and protein identification}

Protein secretion was determined by SDS-PAGE. All the strains and mutants were grown for 18 hours in $\mathrm{LB}$ medium at $37^{\circ} \mathrm{C}$ to reach $\mathrm{OD}_{600 \mathrm{~nm}} 0.8$. To characterise total cellular protein, $120 \mu \mathrm{l}$ of bacterial culture was pelleted by centrifugation $\left(7000 \mathrm{~g}, 15 \mathrm{~min}, 4^{\circ} \mathrm{C}\right)$, resuspended in SDS-PAGE loading buffer (20\% SDS, 25\% glycerol, 0.5\% B-mercaptoethanol, $0.06 \mathrm{M}$ Tris-HCl, pH 6.8, $0.15 \%$ bromphenol blue), heated at $95{ }^{\circ} \mathrm{C}$ for 10 minutes and loaded onto 

diluted and plated on LB agar plates for overnight culture at $37^{\circ} \mathrm{C}$. TOF/TOF exactly as described previously (Straskova et al., 2009).

\section{Invasion tissue culture cells}

$12 \%$ polyacrylamide gel. Secreted proteins were precipitated from $20 \mathrm{ml}$ filtered (Millex GP filter $0.22 \mu \mathrm{m}$, Millipore) bacterial culture supernatant with trichloracetic acid (13\% final concentration). After 1 hour incubation on ice, the precipitated proteins were centrifuged (7000g, $10 \mathrm{~min}, 4^{\circ} \mathrm{C}$ ) and washed twice with ice-cold acetone. Finally the protein pellet was air dried and dissolved in $200 \mu 1$ of $10 \%$ SDS. Total protein was determined by BCA assay and protein samples were diluted to $100 \mu \mathrm{g} / \mathrm{ml}$ concentration. In the case of proteins secreted by the $r f a C$ mutant we were unable to get proteins at a concentration of $100 \mu \mathrm{g} / \mathrm{ml}$ and all the proteins available were therefore loaded onto polyacrylamide gel. SDS-PAGE was performed using Mini Protean II system (Bio-Rad) and gels were stained with Coomassie brilliant blue. Individual protein bands were cut out from the polyacrylamide gel and identified by MALDI-

The IPEC-J2 porcine epithelial cell line was grown on a 24 -well microplate at $37{ }^{\circ} \mathrm{C}$ under $5 \% \mathrm{CO}_{2}$ atmosphere. When the cultures reached semiconfluent growth, $S$. Typhimurium and the $r f a C$ mutant from the 6 hour old LB culture were added at a multiplicity of infection equal to 5. The numbers of adhered and invaded $S$. Typhimurium cells were determined by a standard gentamicin protection assay - counts of total adhered and invaded bacteria were determined 2 hours post Salmonella inoculation after lysing the cells with Triton X-100 (1\% $\mathrm{v} / \mathrm{v})$ and the counts were expressed as percentage of the adhered bacteria out of inoculum. To determine the counts of invaded bacteria, gentamicin (final concentration $100 \mu \mathrm{g} / \mathrm{ml}$ ) was added to kill extracellular bacteria for 2 hours and after that, the tissue culture cells were lysed with $1 \%$ Triton X-100 to release intracellular bacteria. The released bacteria were serially 
Western blot analysis

115 SDS-PAGE-separated proteins were electroblotted onto a Hybond ${ }^{\mathrm{TM}}-\mathrm{P}$ PVDF membrane

116 according to the instructions of the manufacturer (Amersham, GE Healthcare). After blocking

117 with $0.1 \%$ Tween and $0.5 \%$ casein hydrolysate in PBS, the membrane was incubated with

118 primary monovalent $\mathrm{H}: \mathrm{i}$ antibody (Bio-Rad) diluted 1:100 in PBS for 1 hour. After washing

119 with $0.1 \%$ Tween in PBS, the membrane was incubated for another 1 hour with a secondary

120 anti-rabbit antibody conjugated with horse-radish peroxidase. 3,3'-Diamino-benzidin-

121 tetrahydrochlorid (Serva) was finally used for the colorimetric signal development.

Microarray analysis

124 Microarray chips were prepared by spotting 5' amino linker modified 70mer oligonucleotides

125 covering both the $S$. Typhimurium and $S$. Typhi genomes (The Salmonella Genus AROS

126 V1.0, Operon, Germany). The oligonucleotides were resuspended in Micro Spotting Solution

127 Plus buffer (Telechem International, Inc., Sunnyvale, USA) and spotted onto Nexterion Slide

128 E Epoxysilane Coated Substrate microarray glasses (Nexterion, Jena, Germany). For RNA

129 preparation, both strains were grown statically in $10 \mathrm{ml}$ of LB broth for 16 hours at $37{ }^{\circ} \mathrm{C}$,

130 bacterial cultures were pelleted and total RNA was purified using RNeasy Mini kit (Qiagen).

131 At least $5 \mu \mathrm{g}$ of RNA was reverse transcribed with Cy3 or Cy5-labeled dCTP and hybridised

132 to the microarray slides, which were subsequently washed and scanned exactly as described

133 previously (Sebkova et al., 2008). Expression profiles were obtained from 3 independent

134 experiments, each performed in dye-swap design. Data were normalised using statistical

135 software R (Wit and McClure, 2004). Only the spots flagged as of good quality were included

136 into the analysis and were further examined with three approaches: i) t-test with subsequent q-

137 value package for p-value multiple adjustment (Dabney and Storey, 2002), ii) limma linear

138 modeling package (Smyth, 2004) and iii) smida package of Significance Analysis of 
139 Microarrays (Tusher et al., 2001). Full raw microarray data have been deposited in the NCBI

140 GEO database under accession number GSE19878.

Negative staining of bacterial cells from liquid culture

143 Bacterial strains from 18-hour-old LB cultures grown at $37^{\circ} \mathrm{C}$ were centrifuged at $2500 \mathrm{~g}$ and

144 washed with 0.1 M HEPES pH 7.4. A single drop of culture was placed on formvar-coated

145 copper grids and the bacteria were allowed to attach for $5 \mathrm{~min}$. In the next step, the bacteria

146 were stained with $1 \%$ ammonium molybdate and observed with a Philips EM 208

147 transmission electron microscope under an acceleration of $90 \mathrm{kV}$. At least 150 different cells

148 were observed and the numbers of cells with zero, 1-2, and 3 or more flagella was

149 determined.

Detection of flagellin in ultrathin sections

152 One $\mathrm{ml}$ of 18 -hour-old culture was centrifuged at 2500g, washed with HEPES and the pellet was resuspended in $100 \mu \mathrm{l}$ of $4 \%$ gelatine warmed to $45^{\circ} \mathrm{C}$. After gelatine solidification, each

154 sample was cut into 1 to $3 \mathrm{~mm}^{3}$ blocks which were fixed with a mixture of $3 \%$ glutaraldehyde 155 and $2 \%$ paraformaldehyde (1:1), and prestained with $0.25 \%$ ruthenium red for one hour.

156 Samples were then dehydrated with acetone and embedded in Lowicryl K4M (Sigma).

157 Embedded samples were UV photopolymerized for 2 days at room temperature and $100 \mathrm{~nm}$

158 ultrathin sections were prepared using a LKB ultramicrotome. The ultrathin sections were

159 transferred to formvar-coated copper grids and incubated for $10 \mathrm{~min}$ in blocking solution

$160(0.5 \mathrm{M} \mathrm{NaCl}$ containing $0.1 \% \mathrm{BSA}, 0.05 \%$ Tween and $5 \%$ fetal bovine serum, $\mathrm{pH} 7.5)$ for 10

161 min. The grids were first allowed to react with 10x diluted rabbit monovalent $\mathrm{H}: \mathrm{i}$ antiserum

162 (BioRad) for 20 min followed by rinsing 3 times with distilled water. In the next step, the

163 grids were incubated for 20 min with a drop of anti-rabbit antibody conjugated with $10 \mathrm{~nm}$ 
164

165

colloidal gold (Sigma) diluted 1:10 in blocking solution. Finally, the labeled ultrathin sections were stained with uranyl acetate and lead citrate and observed with a transmission electron microscope.

\section{Results}

Protein secretion in the rfaC mutant of $S$. Typhimurium

Major secreted proteins identified by MALDI-TOF/TOF in the wild type strain included SipA, FlgK, FliC, FliD, SipC, InvJ and FlgL, similar to Komoriya et al. (1999). On the other hand, none of the flagellar or SPI-1-encoded proteins were detected in culture supernatants of the $r f a C$ mutant. Complementation with the $\mathrm{pRfaC}$ plasmid restored the ability of the mutant to secrete proteins, although the profile of the complemented mutant was slightly different from the secretion profile of the wild type $S$. Typhimurium (Fig. 1). Similar to observations of Sheng et al. (2008), complementation affected the size of secreted flagellin but we did not study this in more detail.

\section{Motility and flagella expression}

Since defects in secretion of flagellar proteins should correlate with defects in motility, motility in $0.3 \%$ agar was tested in next experiment. The $S$. Typhimurium $r f a C$ mutant exhibited a defect in motility as the diameter of growth 8 hours post inoculation was around $20 \mathrm{~mm}$ while the diameter of the growth halo of the wild type $S$. Typhimurium reached values around $65 \mathrm{~mm}$ (Fig. 2).Complementation with pRfaC plasmid only partially restored motility of the $r f a C$ mutant in $0.3 \%$ agar (Fig. 2) which could be caused by the overexpression of the $\mathrm{RfaC}$ from the multicopy plasmid pCR2.1. 
In the next step we therefore studied the presence of flagella on the surface of the $r f a C$ mutant

189 directly by electron microscopy. Majority of the wild type $S$. Typhimurium expressed flagella on the bacterial surface whilst only around $8 \%$ cells of the $r f a C$ mutant expressed flagella and

191 the number of non-flagellated cells in the $r f a C$ mutant reached $92 \%$. Complementation with

$192 \mathrm{pRfaC}$ plasmid fully restored flagella expression on the surface of the cell (Fig. 3). In

193 addition, a distinct electron dense capsule was observed in the $r f a C$ mutant, consistent with

194 previous reports on the overexpression of capsule in rough mutants (Parker et al., 1992).

\section{Cell invasion}

197 Since defects in secretion of SPI-1-encoded proteins should correlate with defects in cell

198 invasion, invasion of IPEC-J2 cell line was tested in the next experiment. The $r f a C$ mutant

199 tended to be more adherent to the IPEC-J2 cell line, consistent with our previous report

200 (Matiasovic et al., 2011). The $r f a C$ mutant of $S$. Typhimurium was also disabled in its

201 invasion of the same cell line and this defect could be complemented with the pRfaC plasmid 202 (Fig. 4).

Gene expression in $S$. Typhimurium rfaC mutant

Next we were interested whether the decrease in protein secretion could be caused by a decrease in gene transcription since reports of altered transcription in rough mutants have been published (Bauer and Welch, 1997; Nagy et al., 2006). To test this, we compared gene

208 expression in the wild type $S$. Typhimurium and the $r f a C$ mutant by microarray analysis.

209 Although fluorescent signals of 3963 spots (out of 6144 spots present on chips) were classified by the ScanArray Express software as of good quality, none of them was

211 differentially expressed in the wild type $S$. Typhimurium and the $r f a C$ mutant after their 18 212 hour growth in LB broth. 
214 Western blot analysis

215 The absence of protein secretion with a pattern of maintained transcription suggested that the 216 secreted proteins may accumulate in the bacterial cytoplasm. To address this, we separated

217 secreted and whole cellular proteins of $S$. Typhimurium by SDS-PAGE, and performed 218 western blot analysis using anti-flagella antibodies. Western blot confirmed that significantly 219 more FliC protein was secreted by the wild type strain than by the $r f a C$ mutant, as expected 220 based on a visual inspection of Coomassie blue stained polyacrylamide gels. However, when 221 the FliC protein was detected by western blot in total cellular protein, less FliC was observed 222 in the wild type $S$. Typhimurium than in the $r f a C$ mutant (Fig. 5).

Immune electron microscopy of $S$. Typhimurium rfaC mutant

225 Our results suggested that the defect in the $r f a C$ mutant was at the level of protein

226 translocation across the inner and outer membranes. To test this, we finally analysed the 227 spatial distribution of flagellin inside $S$. Typhimurium cells using ultrathin sections and 228 immune electron microscopy. Specific gold-labeled antibodies confirmed that both the wild 229 type $S$. Typhimurium and the $r f a C$ mutant expressed flagella antigens since these could be detected in both these strains. However, while the flagellin in the $r f a C$ mutant was randomly

231 distributed along the inner surface of the cytoplasmic membrane, in the wild type $S$.

232 Typhimurium the flagellin was clustered to spatially discerned loci (Fig. 6). This indicated 233 that incomplete LPS of the $r f a C$ mutant did not allow the flagellar machinery to set up 234 properly and transport flagellin out of the cell.

\section{Discussion}


In this study we have shown that mutation in $r f a C$ gene cause defects in protein secretion, motility or cell invasion in $S$. Typhimurium. Similar to many previous reports (Parker et al., 1992; Genevaux et al., 1999; Nagy et al., 2006; Sheng et al., 2008), but different from Toguchi et al. (2000) and Inoue et al. (2007), the $r f a C$ mutant was defective in motility. The different results in the two studies are likely to be associated with a different strain background and particular experimental procedures used. Mutant in $r f a C$ produce an oligosaccharide core free LPS (Parker et al., 1992; Sirisena et al., 1992; Genevaux et al., 1999) suggesting that the oligosaccharide LPS core is important for the assembly of flagella and protein secretion including cell invasion. Using microarray analysis, we excluded the hypothesis of significantly altered RNA transcription in the $r f a C$ mutant, although this was surprising considering the many defects associated with $r f a C$ mutations (Nagy et al., 2006; Karasova et al., 2009) and the fact that Nagy et al. (2006) determined the expression of $r f a H$ and $r f a G$ mutants in $S$. Typhimurium by microarray analysis and observed a decrease of SPI-1 and flagellar gene expression. We therefore checked the quality of spots containing the probes complementary to SPI-1 gene mRNA individually and even this additional verification step did not indicate any difference in the expression of these genes in the wild type $S$.

Typhimurium and the $r f a C$ mutant. We concluded that there is no or very small decrease in the expression of SPI- 1 genes in the $r f a C$ mutant, and that the differences in the results of microarray analysis can be explained by different culture conditions and time of growth prior to RNA purification when shaken cultures were used by Nagy et al. whereas we used a static overnight culture instead.

Using western blot analysis and immune electron microscopy we next excluded the hypothesis of significantly altered translation or protein stability in the $r f a C$ mutant because western blot analysis clearly indicated that the amount of the FliC protein was either the same 
262

263

264

265

266

267

268

269

270

271

272

273

274

275

276

277

278

279

280

281

282

283

284

285

286

or even slightly higher in the cytoplasm of the $r f a C$ mutant than in the cytoplasm of the wild type $S$. Typhimurium. This was also confirmed by immune electron microscopy using ultrathin sections and we therefore excluded defects at the level of protein expression as a major reason for the aberrant behavior of the $r f a C$ mutant in protein secretion. The only difference could be seen in the distribution of flagellin inside the cells of the wild type strain and the $r f a C$ mutant. In the wild type $S$. Typhimurium, the flagellin was localised to several spatially restricted areas while no such clustering was evident in the $r f a C$ mutant suggesting that the absence of flagellar protein secretion could be caused by the inability of flagellar transport apparatus to assemble correctly.

The presence of FliC in the absence of protein secretion is quite puzzling since based on the current knowledge of hierarchal control of gene expression in flagella assembly, the FliC should not be expressed before the antisigma factor FlgM is secreted out of a cell through a polymerised flagellar hook (Karlinsey et al., 2000b). The size of the LPS molecule is around $10 \mathrm{~nm}$, of which $2.4 \mathrm{~nm}$ is the size of lipid A anchoring the LPS molecule into the outer membrane (Kastowsky et al., 1992). The flagellar hook extends approx. $50 \mathrm{~nm}$ from the bacterial surface (Moriya et al., 2006) and the SPI1 injectisome is of approx. the same size as the flagellar hook (Kubori et al., 2000). This means that if the injectisome or hook polymerisation was initiated, the process would continue above the LPS molecule and therefore independent of its structure. It is therefore likely that incomplete LPS did not allow initiation of injectisome or flagellar hook polymerisation immediately at the outer membrane of $S$. Typhimurium where it can be influenced by LPS structure. Furthermore, if the hookbasal body is not formed, FlgK protein cannot be secreted and may remain associated with the FlgN chaperone (Bennett et al., 2001). Interestingly, if the FlgN is associated with FlgK, it is not available for positive regulation of FlgM expression (Karlinsey et al., 2000a), which may 
287

result in an expression of FliC. FliC can therefore be expressed and accumulate in the cytoplasm even in the tightly controlled flagella expression system, as has been documented for the double $f l g G-L$ and $f l g N$ mutant (Karlinsey et al., 2000a).

\section{Conclusion}

In this study we have found that mutant in $r f a C$ gene exhibited defects in protein secretion via T3SS. The oligosaccharide core of LPS was required for the assembly of flagella and the SPI1 encoded secretion apparatus.

\section{Acknowledgement}

This work has been supported by the projects MZE0002716202 of the Czech Ministry of Agriculture, AdmireVet project CZ.1.05/2.1.00/01.0006 - ED0006/01/01 from the Czech Ministry of Education and EU funded project 035547 SAFEHOUSE. A. Fucikova has been supported by the project of Ministry of Defence MO0FVZ0000501. We would like to thank Prof. Paul A. Barrow, University of Nottingham, UK, for English language corrections.

\section{References}

Bauer, M.E., Welch, R.A., 1997. Pleiotropic effects of a mutation in $r f a C$ on Escherichia coli hemolysin. Infect. Immun. 65, 2218-2224.

Bennett, J.C., Thomas, J., Fraser, G.M., Hughes, C., 2001. Substrate complexes and domain organization of the Salmonella flagellar export chaperones FlgN and FliT. Mol. Microbiol 39, 781-791. 
Cirillo, D.M., Valdivia, R.H., Monack, D.M., Falkow, S., 1998. Macrophage-dependent

310 induction of the Salmonella pathogenicity island 2 type III secretion system and its role in

311 intracellular survival. Mol. Microbiol. 30, 175-188.

312 Dabney, A., Storey, J.D., 2002. Q-value. http:/genomics. princeton. edu/storeylab/qvalue/

313 Genevaux, P., Bauda, P., DuBow, M.S., Oudega, B., 1999. Identification of Tn10 insertions

314 in the $d s b A$ gene affecting Escherichia coli biofilm formation. FEMS Microbiol. Lett. 173, $315 \quad 403-409$.

316 Hautefort, I., Thompson, A., Eriksson-Ygberg, S., Parker, M.L., Lucchini, S., Danino, V., 317 Bongaerts, R.J., Ahmad, N., Rhen, M., Hinton, J.C., 2008. During infection of epithelial cells 318 Salmonella enterica serovar Typhimurium undergoes a time-dependent transcriptional 319 adaptation that results in simultaneous expression of three type 3 secretion systems. Cell. 320 Microbiol. 10, 958-984.

321 Inoue, T., Shingaki, R., Hirose, S., Waki, K., Mori, H., Fukui, K., 2007. Genome-wide 322 screening of genes required for swarming motility in Escherichia coli K-12. J. Bacteriol. 189, $323950-7$.

324 Kaniga, K., Trollinger, D., Galan, J.E., 1995. Identification of two targets of the type III 325 protein secretion system encoded by the inv and spa loci of Salmonella typhimurium that have 326 homology to the Shigella IpaD and IpaA proteins. J. Bacteriol. 177, 7078-7085.

327 Karasova, D., Sebkova, A., Vrbas, V., Havlickova, H., Sisak, F., Rychlik, I., 2009.

328 Comparative analysis of Salmonella enterica serovar Enteritidis mutants with a vaccine 329 potential. Vaccine 27, 5265-5270. 
Karlinsey, J.E., Lonner, J., Brown, K.L., Hughes, K.T., 2000a. Translation/secretion coupling

331 by type III secretion systems. Cell 102, 487-497.

332 Karlinsey, J.E., Tanaka, S., Bettenworth, V., Yamaguchi, S., Boos, W., Aizawa, S.I., Hughes,

K.T., 2000b. Completion of the hook-basal body complex of the Salmonella typhimurium

flagellum is coupled to FlgM secretion and fliC transcription. Mol. Microbiol. 37, 1220-1231.

335

336

337

338

339

340

341

342

343

344
Kastowsky, M., Gutberlet, T., Bradaczek, H., 1992. Molecular modelling of the threedimensional structure and conformational flexibility of bacterial lipopolysaccharide. J. Bacteriol. 174, 4798-4806.

Komoriya, K., Shibano, N., Higano, T., Azuma, N., Yamaguchi, S., Aizawa, S.I., 1999.

Flagellar proteins and type III-exported virulence factors are the predominant proteins secreted into the culture media of Salmonella typhimurium. Mol. Microbiol. 34, 767-779.

Kubori, T., Sukhan, A., Aizawa, S.I., Galan, J.E., 2000. Molecular characterization and assembly of the needle complex of the Salmonella typhimurium type III protein secretion system. Proc. Natl. Acad. Sci. U. S. A. 97, 10225-10230.

Matiasovic, J., Stepanova, H., Volf, J., Kubala, L., Ovesna, P., Rychlik, I., Faldyna, M., 2011. Influence of the lipopolysaccharide structure of Salmonella enterica serovar Enteritidis on interactions with pig neutrophils. Vet. Microbiol. doi:10.1016/j.vetmic.2011.01.007.

Moriya, N., Minamino, T., Hughes, K.T., Macnab, R.M., Namba, K., 2006. The type III flagellar export specificity switch is dependent on FliK ruler and a molecular clock. J. Mol. Biol. 359, 466-477.

Nagy, G., Danino, V., Dobrindt, U., Pallen, M., Chaudhuri, R., Emody, L., Hinton, J.C., Hacker, J., 2006. Down-regulation of key virulence factors makes the Salmonella enterica 
352

353

354

serovar Typhimurium $\mathrm{rfaH}$ mutant a promising live-attenuated vaccine candidate. Infect. Immun. 74, 5914-5925.

Panthel, K., Meinel, K.M., Domenech, V.E., Retzbach, H., Igwe, E.I., Hardt, W.D., Russmann, H., 2005. Salmonella pathogenicity island 2-mediated overexpression of chimeric $\mathrm{SspH} 2$ proteins for simultaneous induction of antigen-specific CD4 and CD8 T cells. Infect. Immun. 73, 334-341.

Parker, C.T., Kloser, A.W., Schnaitman, C.A., Stein, M.A., Gottesman, S., Gibson, B.W., 1992. Role of the $r f a G$ and $r f a P$ genes in determining the lipopolysaccharide core structure and cell surface properties of Escherichia coli K-12. J. Bacteriol. 174, 2525-2538.

Sebkova, A., Karasova, D., Crhanova, M., Budinska, E., Rychlik, I., 2008. aro mutations in Salmonella enterica cause defects in cell wall and outer membrane integrity. J. Bacteriol. 190, 3155-3160.

Sheng, H., Lim, J.Y., Watkins, M.K., Minnich, S.A., Hovde, C.J., 2008. Characterization of an Escherichia coli O157:H7 O-antigen deletion mutant and effect of the deletion on bacterial persistence in the mouse intestine and colonization at the bovine terminal rectal mucosa. Appl. Environ. Microbiol. 74, 5015-5022.

Sirisena, D.M., Brozek, K.A., MacLachlan, P.R., Sanderson, K.E., Raetz, C.R., 1992. The rfaC gene of Salmonella typhimurium. Cloning, sequencing, and enzymatic function in heptose transfer to lipopolysaccharide. J. Biol. Chem. 267, 18874-18884.

Smyth, G.K., 2004. Linear models and empirical bayes methods for assessing differential expression in microarray experiments. Stat. Appl. Genet. Mol. Biol. 3, Article3. 
373 Straskova, A., Pavkova, I., Link, M., Forslund, A.L., Kuoppa, K., Noppa, L., Kroca, M.,

374 Fucikova, A., Klimentova, J., Krocova, Z., Forsberg, A., Stulik, J., 2009. Proteome analysis

375 of an attenuated Francisella tularensis $d s b A$ mutant: identification of potential DsbA

376 substrate proteins. J. Proteome Res. 8, 5336-5346.

377 Toguchi, A., Siano, M., Burkart, M., Harshey, R.M., 2000. Genetics of swarming motility in

378 Salmonella enterica serovar typhimurium: critical role for lipopolysaccharide. J. Bacteriol.

379 182, 6308-6321.

380 Tusher, V.G., Tibshirani, R., Chu, G., 2001. Significance analysis of microarrays applied to

381 the ionizing radiation response. Proc. Natl. Acad. Sci. U. S. A. 98, 5116-5121.

382 Wit, E., McClure, J.D., 2004. Statistics for Microarrays; Design, Analysis and Inference.

383 Chichester. John Wiley \& Sons. 


\section{Figure legends}

Figure 1. Protein secretion in $S$. Typhimurium LT2, its $r f a C$ mutant and the $r f a C$ mutant complemented with pRfaC. Sizes of molecular weight marker (lane M) and proteins identified by MALDI-TOF/TOF are indicated.

Figure 2. Motility of $S$. Typhimurium LT2, its isogenic $r f a C$ mutant and the mutant complemented with recombinant $\mathrm{pRfaC}$ plasmid in $0.3 \% \mathrm{LB}$ agar. Since more strains were inoculated in a single plate for comparison, the assay in this figure was interrupted 3 hours post inoculation when the $r f a C$ mutant still appeared as completely non-motile. However, after 8 hours of motility assay a small amount of growth similar to that described by Genevaux et al. (1999) was observed.

Figure 3. Presence of flagella on the surface of $S$. Typhimurium, $r f a C$ mutant and the $r f a C$ mutant complemented by recombinant $\mathrm{pRfaC}$ plasmid determined by electron microcopy (Panel A). Panel B, numbers of cells without any flagella (white columns), cells expressing 1 or 2 flagella (grey columns), and cells expressing 3 or more flagella (black columns).

Figure 4. Adhesion and invasion of the $r f a C$ mutant of $S$. Typhimurium into an IPEC-J2 porcine epithelial cell line. Panel A, adhesion of $S$. Typhimurium $r f a C$ mutant and the mutant complemented by the $\mathrm{pRfaC}$ plasmid. Panel B, invasion of $S$. Typhimurium $r f a C$ mutant and the mutant complemented by the pRfaC plasmid. * - significantly different by t-test $(\mathrm{P}<0.05)$ from appropriate wild type strain control. 
408 Figure 5. SDS-PAGE (Panel A) and western blot analysis using anti flagellin H:i antibody

409 (Panel B) of secreted and total cellular proteins in wild type $S$. Typhimurium (STM LT2 wt),

$410 r f a C$ mutant and $r f a C$ mutant complemented with recombinant $\mathrm{pRfaC}$ plasmid. Lane $\mathrm{M}$,

411 molecular weight standard.

412

413 Figure 6. Immune electron microscopy in ultrathin section of the wild type $S$. Typhimurium

414 (panel A) and its isogenic $r f a C$ mutant (Panel B) using anti-flagella antibody. Unlike the $r f a C$

415 mutant, in the wild type strain, spatially restricted clusters of flagellin indicated by arrows

416 were observed. 


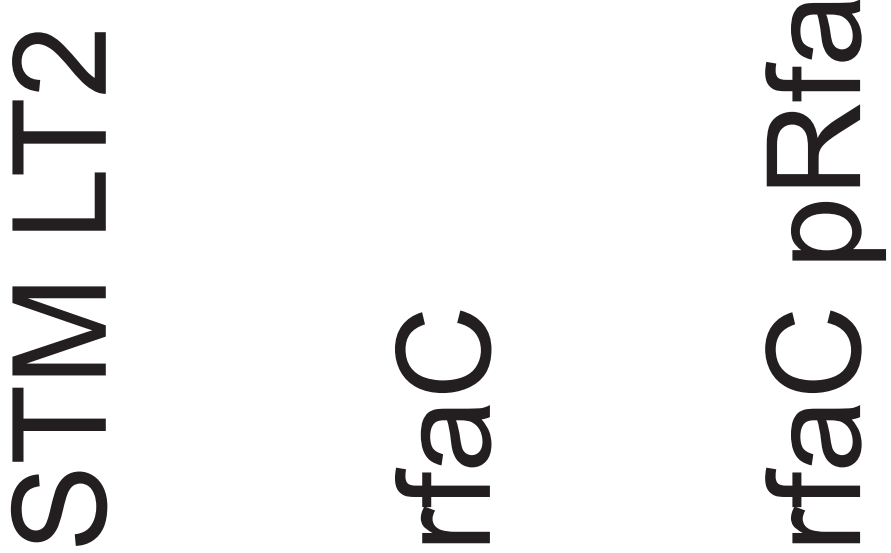

180

116

90

SipA

58

48.5

Flgk
Flic

FliD

SipC

36.5

InvJ

FlgL

26.6

Page 20 of 25

$\mathrm{kDa}$ 


\section{STM LT2 rfac pRfac}


A
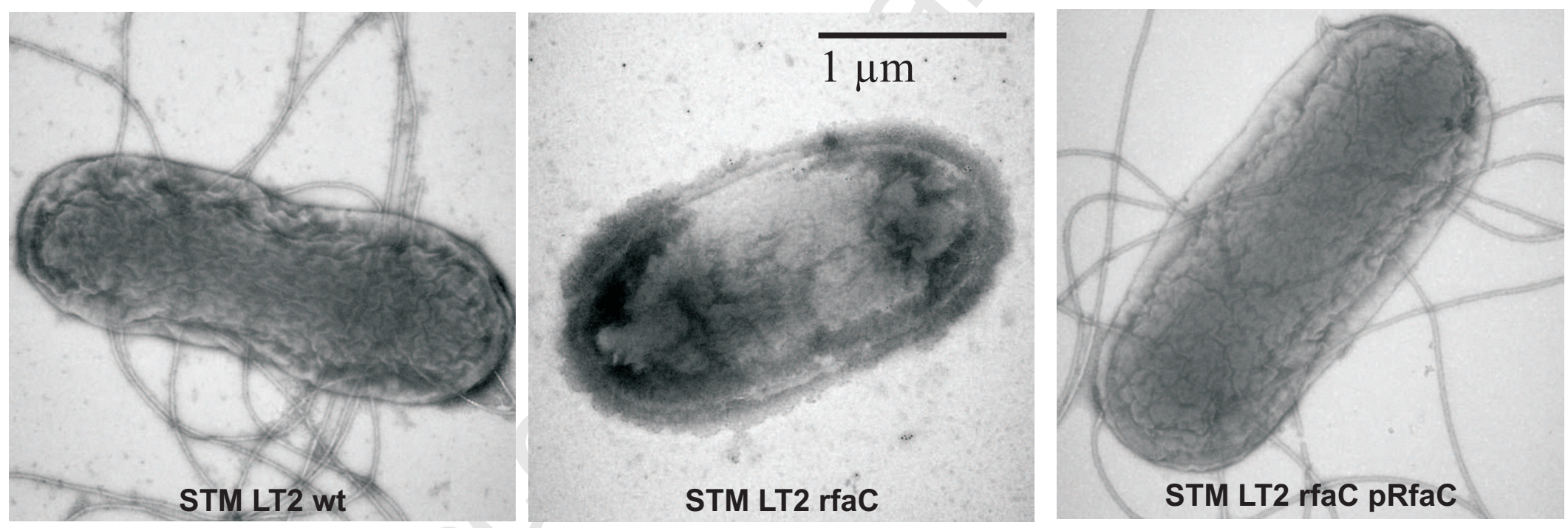

B

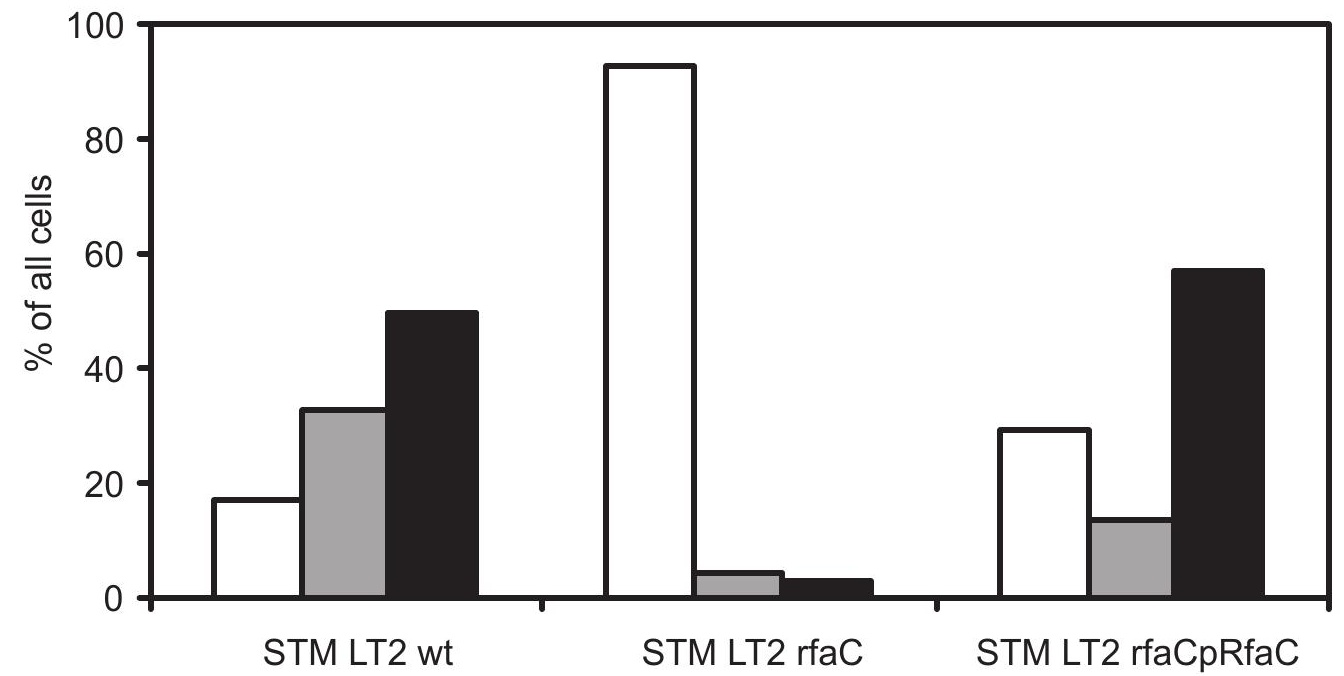


A

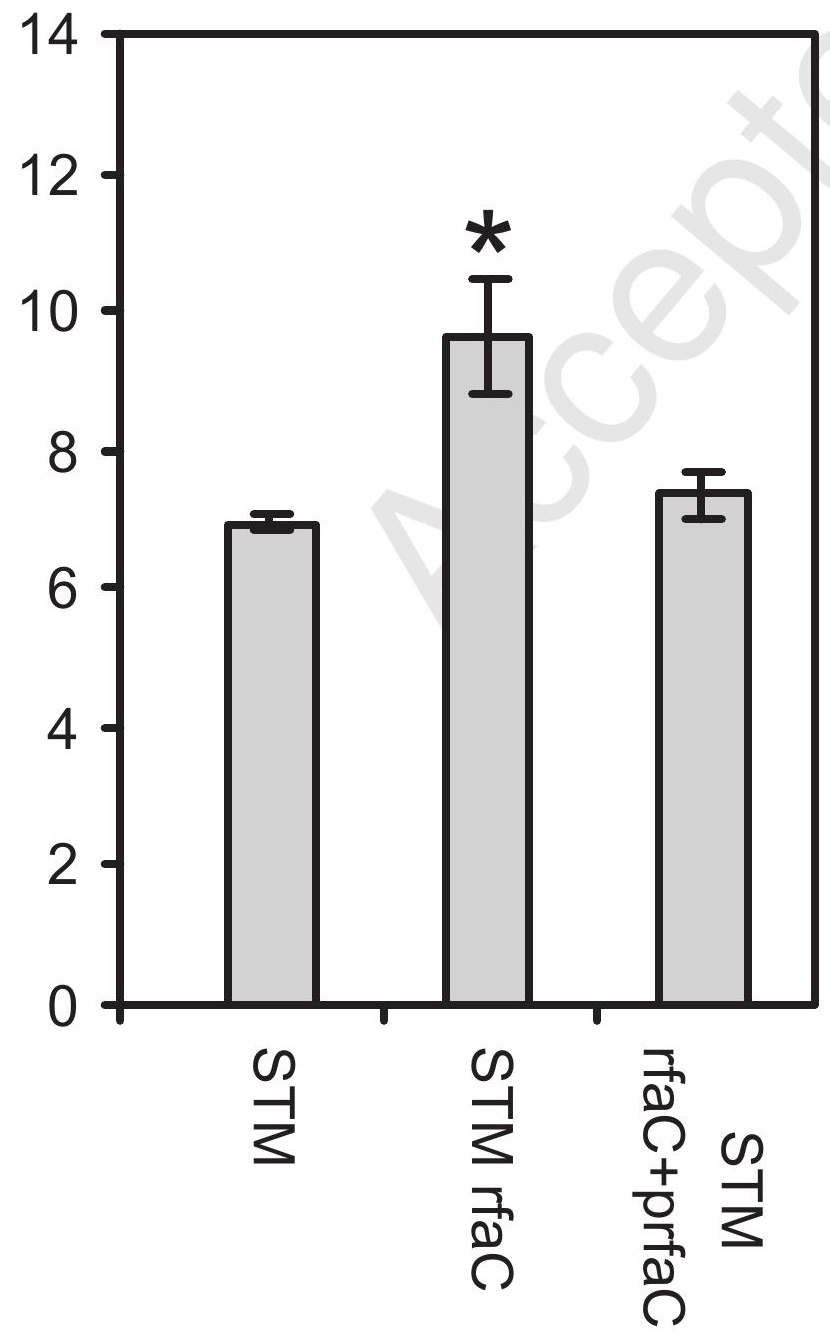

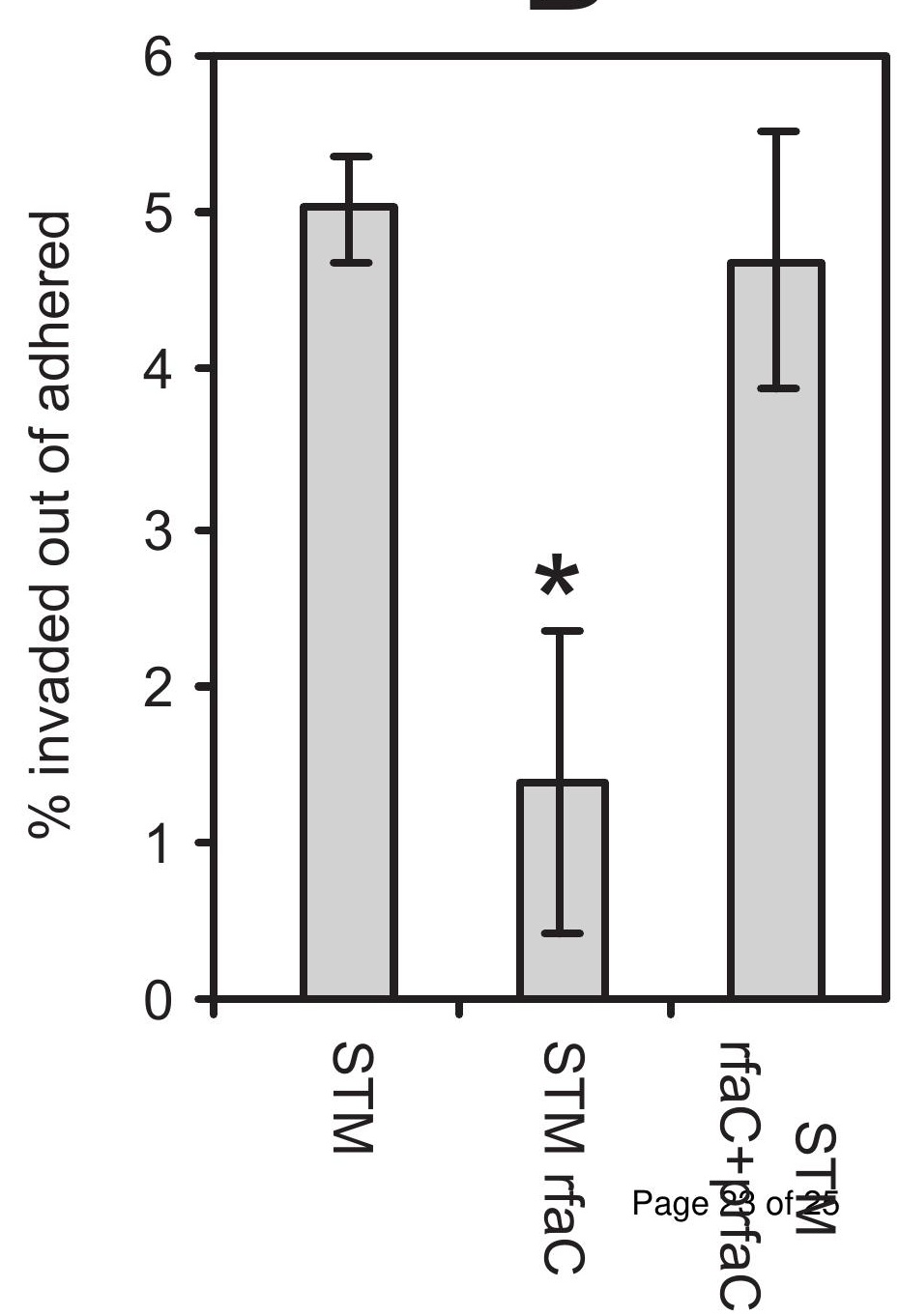

B 
A

B

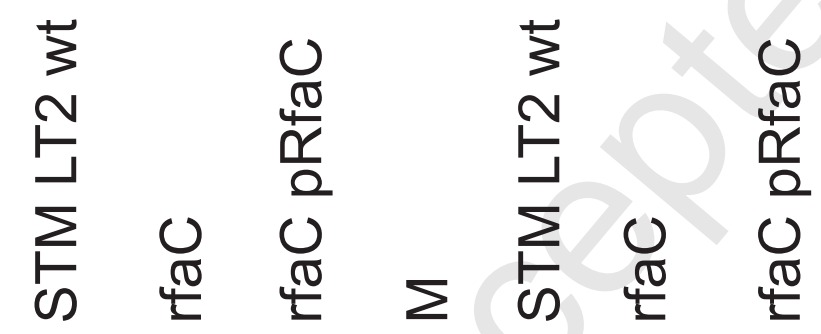

SipA

116

90

58

FliC

FliD

SipC

InvJ

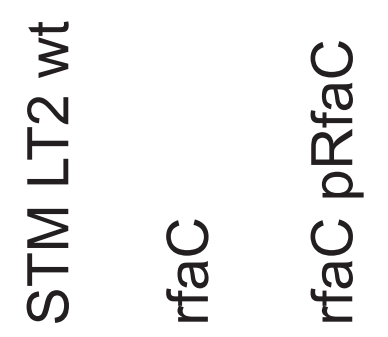

3

I

$\frac{0}{\frac{\pi}{4}}$

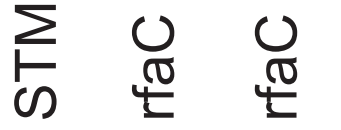

48.5

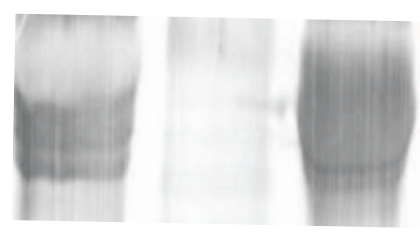

36.5

secreted

cellular

FlgL

26.6

$\mathrm{kDa}$ 
